\title{
Use of water restriction in the inoculation of carrot $\operatorname{seeds}^{1}$
}

\author{
Ricardo Borges Pereira ${ }^{2}$ (D), Tiago B. Torres 3 (D), Patrícia Pereira da Silva² (D), \\ Gilvaine C. Lucas ${ }^{4}$ (D), Jadir Borges Pinheiro ${ }^{2}$ (D), Warley Marcos Nascimento ${ }^{2 *}$ (iD
}

\begin{abstract}
This study aimed at evaluating the method of inoculation of carrot seeds in a potato-dextrose-agar medium (PDA) added of mannitol. Alternaria radicina was the fungus chosen to test such methodology. The osmosis-controlling agent was employed to obtain the osmotic potentials of $0.6 \mathrm{MPa}, 0.8 \mathrm{MPa}, 1.0 \mathrm{MPa}$ and $1.2 \mathrm{MPa}$. In comparison with the control treatment, no significant mycelial growth inhibition was noticed at any of the osmotic potentials considered. The seeds were distributed over the fungal colonies for infection, where they remained for 48, 72, 96, 120 and 144 hours, at the osmotic potentials of 0.0 $\mathrm{MPa}$ (control), 0.6 MPa, 0.8 MPa, 1.0 MPa and 1.2 MPa, respectively. Tests of germination, sanitization and emergence were performed to evaluate the effects of colonization. Regarding the germination, the different osmotic potentials resulted in similar percentages of abnormal seedlings and dead seeds. As for the sanitization testing, higher infection rates were observed at the osmotic potentials of 1.0 MPa and 1.2 MPa. The lowest percentage of emergence was found at $-1.2 \mathrm{MPa}$, therefore suggesting that this osmotic potential (produced with mannitol) might be used for infecting carrot seeds for research purposes.
\end{abstract}

Index terms: Daucus carota, mannitol, seeds infection.

\section{Uso de restrição hídrica na inoculação de sementes de cenoura}

\begin{abstract}
RESUMO - O objetivo deste trabalho foi avaliar o método de inoculação de sementes de cenoura com meio batata-dextroseágar (BDA) acrescido de manitol. O fungo escolhido para testar a metodologia foi o Alternaria radicina. O restritor hídrico foi adicionado ao meio BDA de modo a obter os potenciais osmóticos de 0,6 MPa, 0,8 MPa, 1,0 MPA e 1,2 MPa. O crescimento micelial foi avaliado, e não foi observado inibição do crescimento em nenhum dos potenciais osmóticos, em relação a testemunha. As sementes foram distribuídas sobre as colônias fúngicas para a infecção, onde permaneceram por 48, 72, 96, 120 e 144 horas nos potenciais osmóticos 0,0 MPa (controle), 0,6 MPa, 0,8 MPa, 1,0 MPa e 1,2 MPa, respectivamente. Para avaliar os efeitos da colonização foram realizados testes de germinação, sanidade e emergência. Os potenciais osmóticos avaliados apresentaram porcentagens semelhantes de plântulas anormais e sementes mortas no teste de germinação. No teste de sanidade, maiores porcentagens de infecção foram observadas nos potenciais osmóticos 1,0 MPa e 1,2 MPa. O potencial -1,2 MPa apresentou a menor porcentagem de emergência. Assim, o uso de manitol -1,2 MPa é sugerido como um método eficaz para a infecção de sementes de cenoura com para fins de pesquisa.
\end{abstract}

Termos para indexação: Daucus carota, manitol, infecção de sementes.

\section{Introduction}

Research on the control of seed-borne pathogens often depends on the availability of contaminated grains. For that reason, it is necessary to develop efficient techniques that result in high seed infection rates. Traditionally, seeds are exposed to fungi via imbibition in a suspension of conidia (Pedroso et

${ }^{1}$ Submitted on 1/8/2019. Accepted for publication on 8/4/2019.

${ }^{2}$ Embrapa Hortaliças, Caixa Postal 218, 70359-970 - Brasília, DF, Brasil.

${ }^{3}$ ICESP Promove, 71961-540 - Brasília, DF, Brasil. al., 2010), or through contact with fungal structures (mycelia) grown in conventional culture media. Nonetheless, according to Machado et al. (2001), such practices do not guarantee seed inoculation, once the pathogen might just adhere to the integument, not reaching the inner tissues of the seed.

For that reason, the method of water restriction induced by mannitol $\left(\mathrm{C}_{6} \mathrm{H}_{14} \mathrm{O}_{6}\right)$ is an interesting alternative, as it

${ }^{4}$ Universidade Federal de Lavras, Caixa Postal 3037, 37200-000 - Lavras, MG, Brasil.

*Corresponding author <warley.nascimento@embrapa.br> 
inhibits germination for more extended incubation periods, giving it time for the infection process to take place (Costa et al., 2003; Carvalho et al., 2004). According to Ávila et al. (2007), mannitol has frequently been employed as an osmotic agent to simulate water deficits and, since it is chemically inert, it does not cause structural harm to seeds. However, such premise is not entirely valid, since Menezes et al. (2011) reported the influence of this compound, at different osmotic potentials, on the physiological quality of cucumber seeds.

Some works have already proved the efficiency of this osmosis-controlling agent in facilitating pathogen inoculation in seeds. Machado et al. (2004), for example, used mannitol in a PDA medium (200 $\mathrm{g}$ of potato extract, $20 \mathrm{~g}$ of dextrose, and $20 \mathrm{~g}$ of agar), in order to adjust the osmotic potential to values between $0.8 \mathrm{MPa}$ and $1.0 \mathrm{MPa}$. On that occasion, they obtained good indices of cotton seed infection with Colletotrichum gossypii South var. cephalosporioides Costa, Botryodiplodia theobromae (Pat.) Griffon and Maubl., and Fusarium oxysporum f. sp. vasinfectum (Atk.) Snyder and Hansennos. Machado et al. (2001), using the same methodology but at $0.8 \mathrm{MPa}$ to $1.2 \mathrm{MPa}$, attained high infection rates of maize seeds with the fungi Diplodia maydis (Berk.) Sacc., Cephalosporium acremonium Corda and Fusarium moniliforme J. Sheldon.

In vegetables, the use of water restriction to infect seeds remains little investigated. In works conducted by the phytopathology study group of Embrapa Hortaliças [Brazilian Agricultural Research Corporation], the method of mannitol in a PDA medium proved to be efficient in aiding the inoculation of onion seeds with Colletotrichum gloeosporioides f. sp. cepae (Penz.) Penz. and Sacc. They got the best infection percentages at the osmotic potentials of 1.0 $\mathrm{MPa}$ and 1.2 $\mathrm{MPa}$.

Infected carrot seeds for epidemiologic studies and other purposes are difficult to find. On that account, this work aimed at evaluating the use of mannitol in culture media at different water potentials, in order to achieve high infection rates of carrot seeds by the fungus Alternaria radicina.

\section{Material and Methods}

The research was carried out from November 2015 to February 2016, in the Laboratory of Phytopathology and Laboratory of Seeds, as well as in a greenhouse, all of them belonging to Embrapa Hortaliças, located in Brasília, Distrito Federal.

Carrot leaves exhibiting blight symptoms were collected from an experimental field and then taken to the laboratory, where it was subjected to monosporic isolation of $A$. radicina.
Next, the fungus was grown in a PDA medium (200 $\mathrm{g}$ of potato extract, $20 \mathrm{~g}$ of dextrose, $20 \mathrm{~g}$ of agar) and identified. All assays utilized carrot seeds (cv. Kuronan) from a single lot. They had their vigor and emergence appraised and were deemed as adequate for performing the experiments (at 94\% emergence).

\section{Effect of water restriction on A. radicina development}

To assess the effect of water restriction upon $A$. radicina development, mycelia of the pathogen were cultivated in a PDA medium added of mannitol (182.172 $\mathrm{g} / \mathrm{mol})$, so as to induce water restriction. The osmotic potentials of $0.0 \mathrm{MPa}$ (control treatment, mannitol-free PDA media), -0.6 MPa, -0.8 MPa, -1.0 MPa and -1.2 MPa were considered.

The concentrations used to prepare the culture media of each water potential were determined by the Van't Hoff equation (Souza and Cardoso, 2000):

$$
\mathrm{Po}=\mathrm{C} \times \mathrm{R} \times \mathrm{T}
$$

Where $\mathrm{Po}=$ water potential $(\mathrm{MPa}) ; \mathrm{R}=$ universal gas constant $(0.00831 \mathrm{~kg} \mathrm{MPa} / \mathrm{mol} / \mathrm{K}) ; \mathrm{T}=$ absolute temperature $\left({ }^{\circ} \mathrm{C}+273\right)$; and $\mathrm{C}=$ concentration (moles $/ \mathrm{kg}$ of water). The temperature of $25^{\circ} \mathrm{C}$ was assumed as reference in this case.

After the media containing mannitol had been prepared, approximately $25 \mathrm{~mL}$ was poured into Petri dishes. Once they solidified, a 5-millimeter disc carrying culture medium with young mycelia of the fungus was placed in the center of each unit. Next, the dishes were sealed with transparent plastic film and stowed inside a BOD incubator chamber set at $25^{\circ} \mathrm{C}$ and 12-hour photoperiod.

The experiment complied with a completely randomized design, with five treatments and seven replications, each one composed of a 90-millimeter Petri dish. The diameter of the colonies was measured periodically, for seven days, until the fungus colony in the control treatment covered the whole media surface. The mycelial growth rate (MGR) was determined through the equation proposed by Maguire (1962).

\section{Seed inoculation with $A$. radicina}

Carrot seeds were previously disinfected in a $1 \%$ sodium hypochlorite solution for $1 \mathrm{~min}$. Then, they were rinsed with distilled water and left to dry at room temperature for about $1 \mathrm{~h}$.

The fungus totally overspread the culture media eight days after it had been streaked in all osmotic potential treatments. So, 160 seeds were placed on each dish, gently pressing them over the mycelia with a Drigalski spatula. After that, the sets returned to the incubator (at $25^{\circ} \mathrm{C}$ and a 12-hour photoperiod), where they remained until at least one seed within each treatment started to show radicle protrusion. That way, seeds were taken off of the incubator after 48, 72, 96, 120 and 144 
hours, corresponding to the osmotic potential of $0.0 \mathrm{MPa}$, $-0.6 \mathrm{MPa},-0.8 \mathrm{MPa},-1.0 \mathrm{MPa}$ and $-1.2 \mathrm{MPa}$, respectively.

The seeds were laid over filter paper to dry at room temperature for about $1 \mathrm{~h}$. The result was small lots, each one containing around 1,400 seeds from each treatment. Subsequently, these sets were tested for germination, sanitization effect and emergence in soil, in order to appraise the efficacy of the infection method.

\section{Germination test}

The seeds were distributed in plastic Gerboxes containing two germination-paper sheets, which had been previously moistened with distilled water at a ratio of 2.5 times the dry substrate weight. After the boxes had been set up with fifty seeds in each, they were placed inside a germinator adjusted to $25^{\circ} \mathrm{C}$ and 12-hour photoperiod, where they stayed for seven days before the testing. Besides the treatments holding infected seeds and the osmosis-controlling agent, another one was included, containing uninoculated seeds (absolute control).

The experiment was performed in a completely randomized design with six treatments and four replications, each one represented by a Gerbox enclosing fifty seeds. The analyses determined the percentages of normal and abnormal seedlings, as well as the rate of dead seeds, according to the Rules for Seed Testing (Brasil, 2009). The normal seedlings comprised those exhibiting intact vital structures, those with less than $50 \%$ malformed tissues, and also the ones with infection signs (as long as the seed was not the source of it). In turn, seedlings with either damaged or poorly formed essential structures, or which showed fungal deterioration or albinism traces were deemed abnormal. Lastly, non-germinated seeds, which by the end of the test presented themselves swollen and infected by the pathogen, were considered dead.

\section{Sanitization testing}

The sanitization test was evaluated via incubation in a paper substrate. This analysis contemplated not only the experimental groups combining infected seeds and the osmosis-regulating agent, but also an additional one, with uninoculated seeds (absolute control). One hundred grains from each of those treatments were sanitized separately in a $1.0 \%$ sodium hypochlorite solution for $1 \mathrm{~min}$; while another similar set of one hundred seeds remained disinfected. Twenty-five seeds from each treatment were spread inside plastic Gerboxes containing two germination-paper sheets, which had been previously moistened with distilled water at the ratio of 2.5 times the dry substrate weight. Next, the boxes were placed inside an incubation chamber set at 25 ${ }^{\circ} \mathrm{C}$, for the first $24 \mathrm{~h}$, then at $-20^{\circ} \mathrm{C}$, for another $24 \mathrm{~h}$ and, finally, at $25{ }^{\circ} \mathrm{C}$ and 12-hour photoperiod, for seven days prior to the evaluation.

The experiment employed a completely randomized design, considering twelve treatments (with and without sodium hypochlorite) and four replications, each one representing one Gerbox with 25 seeds. The effect of sanitization was checked by observing the seeds in a stereomicroscope. The seeds that had been disinfected with sodium hypochlorite and later presented A. radicina reproductive structures were considered contaminated.

\section{Emergence test}

Four subsamples with one hundred seeds from each treatment - the ones containing osmosis-controlling agents and also that with uninoculated seeds (absolute control) - were sown at 1.5 centimeter depth, in plastic trays filled with autoclaved substrate. This substrate had been prepared by mixing $85 \%$ of soil, $5 \%$ of dried rice husk and $10 \%$ of carbonized rice husk (v:v). After sowing, the sets were randomly distributed inside a greenhouse, where they were irrigated as needed, with equal volumes of water to each tray.

This experiment followed a completely randomized design, with six treatments and four replications, each one consisting of a tray with fifty seeds. The assessments were performed seven and 21 days after sowing. In the last evaluation, the seedlings were collected and analyzed for symptoms of disease caused by $A$. radicina. The results were conveyed in percentage of normal seedlings.

\section{Statistical analysis}

The data from the tests of germination, sanitization and emergence were subjected to variance analysis, and the means were grouped by the Scott-Knott test $(p \leq 0.05)$. All statistical procedures were handled by the software Sisvar (v.5.6).

\section{Results and Discussion}

\section{Effect of water restriction on A. radicina growth}

The osmotic potentials of $0.6 \mathrm{MPa}$ to $1.2 \mathrm{MPa}$, promoted by the addition of mannitol to the culture media, did not significantly affect $A$. radicina mycelial development. Similar results were observed by Carvalho et al. (2009), who assessed the proliferation of $A$. dauci in PDA media adjusted with mannitol to between $0.4 \mathrm{MPa}$ and 1.2 $\mathrm{MPa}$. On the other hand, the same authors confirmed a substantial decrease in A. radicina growth at the values of $1.0 \mathrm{MPa}$ and $1.2 \mathrm{MPa}$. Such a difference could be attributed to characteristics of either the isolate or cultivation conditions, like temperature and photoperiod. More recently, Reis et al. (2014) verified that 
the addition of mannitol to PDA media, so as to achieve the osmotic potentials of $0.3 \mathrm{MPa}, 0.6 \mathrm{MPa}$ and $0.9 \mathrm{MPa}$, did not curb the mycelial development of Sclerotinia sclerotiorum.

\section{Germination test}

The test showed that seeds that had not been exposed to contamination (absolute control) had the highest germination rates $(89 \%)$. The following highest values were achieved by the control treatment (PDA medium with no mannitol) and those with osmotic potentials of -0.6 MPa and $0.8 \mathrm{MPa}$ - in fact, these sets did not statistically differ from one another, exhibiting from $6 \%$ to $11 \%$ of normal seedling emergence (Figure 1). The seeds inoculated at $1.0 \mathrm{MPa}$ and $1.2 \mathrm{MPa}$ presented the lowest percentages, with $0.5 \%$ and $1.0 \%$ of emerged normal seedlings, respectively.

Except for the absolute control, which scored $0.5 \%$ of abnormal seedlings and $14 \%$ of dead seeds, the remaining experimental groups with contaminated seed presented superior rates of abnormal seedlings (from 57\% to $71 \%$ ) and dead seeds (from $29 \%$ to $42 \%$ ), regardless of the osmotic potential considered. Also, they did not differ from one another nor from the PDA control treatment.

According to the observed results, the inoculated treatments prompted high percentages of both abnormal seedlings and perished seeds ( $95 \%$, on average). However, significant augments in the number of dead seeds might make the infection unfeasible for any further use, including epidemiologic studies and the development of new methods for managing and treating seeds.

In the present study, the ratio of abnormal seedlings and dead seeds was somewhat similar among the inoculated experimental groups, even though the more prolonged exposition of seeds matched the higher osmotic potentials. Machado et al. (2001) used similar potential values and verified that maize seeds contaminated with the fungi Diplodia maydis, Cephalosporium acremonium and Fusarium moniliforme displayed higher percentages of abnormal seedlings at the most negative osmotic potentials. Costa et al. (2003), when employing different solutes and exposure times, realized that the longer the contact with Fusarium oxysporum f. sp. phaseoli, the more compromised the germination of bean seeds. Ultimately, Machado et al. (2004) proved that cotton seeds inoculated with Colletotrichum gossypii, C. gossypii var. cephalosporioides and F. oxysporum f. sp. Vasinfectum also presented percentages of abnormal seedlings and unviable seeds significantly higher at the negative osmotic potentials, in comparison with the control treatments.

According to the authors, the expressive rise in the number of abnormal seedlings and dead seeds is a reflex of the higher inoculation potential, as a consequence of the more extended contact with the pathogen. Nevertheless, seeds exposed to high osmotic potentials for too long may lose their germination capacity, as Teixeira et al. (2005) detected in maize seeds subjected to osmotic potentials above $1.0 \mathrm{MPa}$ for eight incubation days. Such results indicate that the physiological quality of the seeds might be affected by both

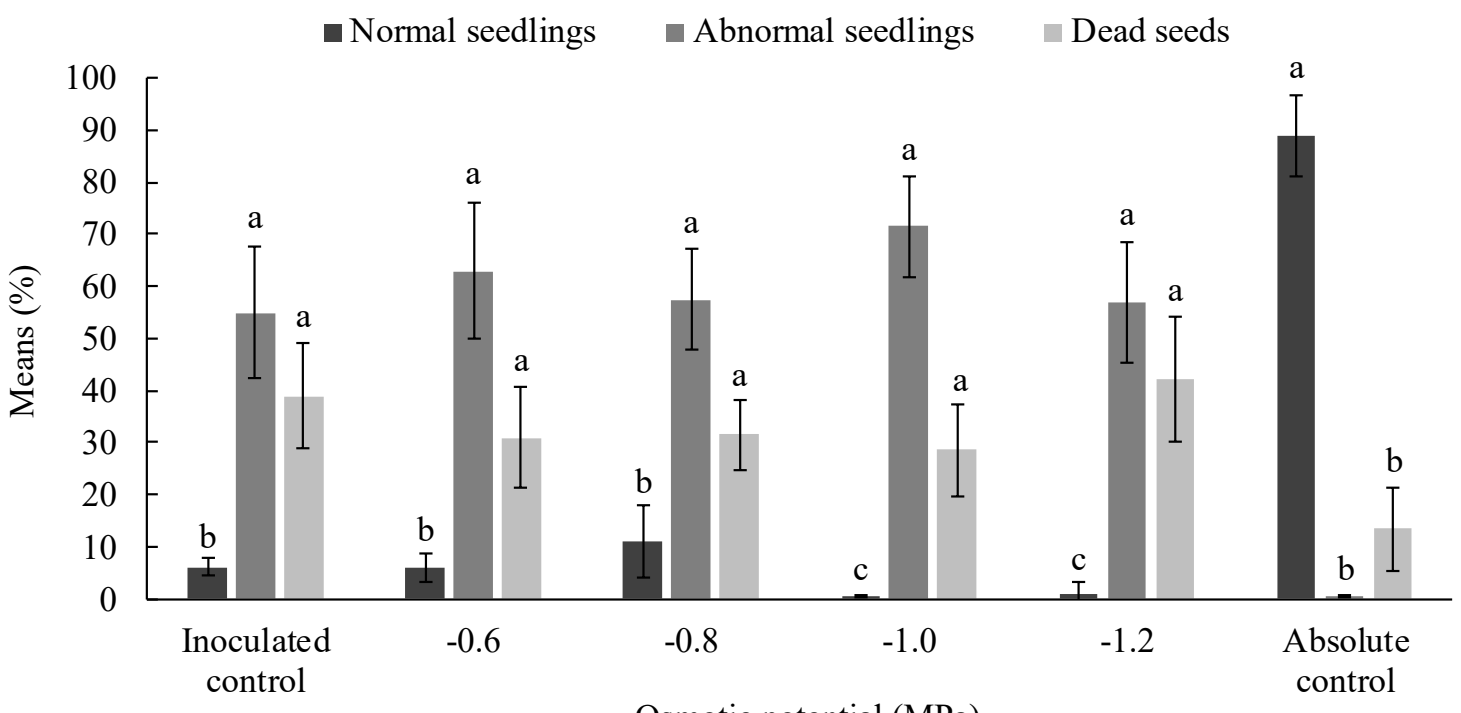

Osmotic potential (MPa)

Figure 1. Percentage of normal and abnormal emerged seedlings and dead carrot seeds seven days after inoculation with $A$. radicina at different osmotic potentials.

Means followed by the same letter statistically do not differ, according to Tukey's test at a 5\% probability level. 
the exposure time and the osmotic conditioning imposed by the culture medium.

\section{Sanitization testing}

In the Sanitization testing, $100 \%$ of the non-disinfected seeds got infested after exposition to A. radicina in a PDA medium, either pure (control treatment) or in combination with mannitol (Figure 2). On the other hand, the seeds that had been contaminated and then sanitized with a sodium hypochlorite solution showed significant reductions in the infestation rates at the osmotic potentials of $0.6 \mathrm{MPa}(60 \%)$ and $0.8 \mathrm{MPa}(65 \%)$ - in these cases, the results did not differ from the control treatment. The seeds subjected to $1.0 \mathrm{MPa}$ and 1.2 $\mathrm{MPa}$ also presented $100 \%$ infestation. Ultimately, in the absolute control, the pathogen was detected in neither infected nor disinfected seeds.

Galli et al. (2005) defined infested seeds as those in which the pathogen is adhered to the grain surface, whereas the infected ones have it in their inner tissues. Once the disinfection with sodium hypochlorite had removed the A. radicina inoculum from seed pericarp, the osmotic potentials of 1.0 MPa and 1.2 MPa proved to be the most efficient configurations to promote the contamination of the seeds. This outcome is probably related to the more extended exposition to the fungus (120 h and $144 \mathrm{~h}$, respectively). In the mannitol-free PDA medium and in those with low water restriction $(0.6 \mathrm{MPa}$ and $0.8 \mathrm{MPa})$, there was an enormous and significant difference between the infection rates of disinfested and non-disinfested seeds. In these cases, the seeds had remained less time in contact with the fungus $(48,72$ and
$96 \mathrm{~h}$, respectively), which suggests that the exposure was not enough for the pathogen to penetrate to the inner structures.

Costa et al. (2003) observed that prolonged periods of incubation of bean seeds led to higher percentages of colonization by $F$. oxysporum f. sp. phaseoli, consequently producing different levels of infestation. In turn, Machado et al. (2001) concluded that maize seeds inoculated with $D$. maydis and $C$. acremonium conveyed higher infection rates when kept at a more negative osmotic potential (1.2 MPa for $120 \mathrm{~h}$ ). Similar results were achieved by Barrocas et al. (2014) when researching cotton seeds treated with C. gossypii var. cephalosporioides. Conversely, this very study revealed a high percentage of infection in maize seeds inoculated with the fungus $F$. moniliforme, at the osmotic potentials of $0.4 \mathrm{MPa}$ to $1.0 \mathrm{MPa}$ and also without water restriction. This is an indication that this pathogen grows fast and easily penetrates the protective layers of the seed. Ultimately, Machado et al. (2004) noticed considerable differences in the infection rates of cotton seeds that had been contaminated with C. gossypii, C. gossypii var. cephalosporioides, Botryodiplodia theobromae and $F$. oxysporum f. sp. vasinfectum at $0.4 \mathrm{MPa}$ to $1.2 \mathrm{MPa}$.

All facts considered, it is safe to say that the efficiency of the infection method varies enormously, depending on the osmotic potential, the seed species and the pathogen used in each case.

\section{Test of emergence in soil}

Carrot seeds that had been subjected to inoculation without water restriction showed emergence of $22 \%$ after 7 DAS. For the same period, seeds that had been treated at 0.6 MPa exhibited $11 \%$ emergence (Figure 3), whereas those exposed to more negative osmotic potentials or that had not

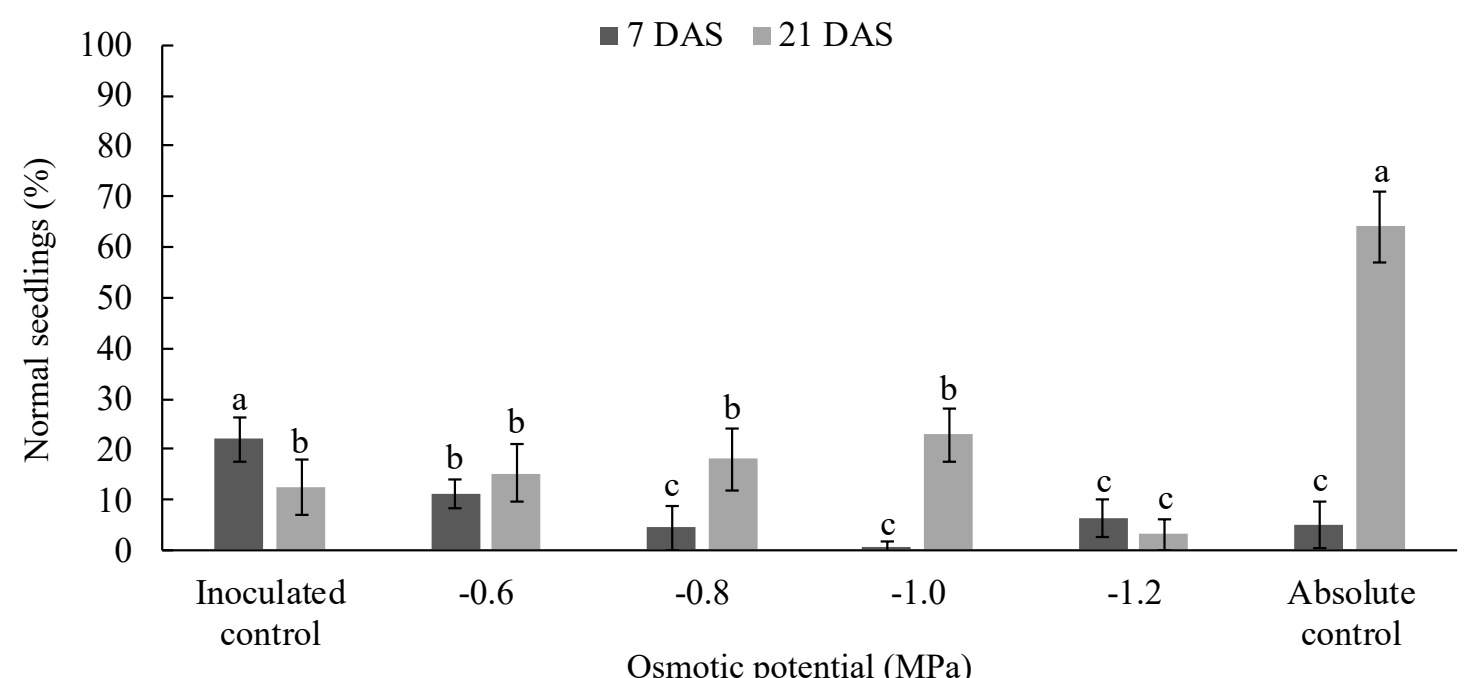

Figure 2. Percentage of infestation by Alternaria radicina of carrot seeds seven days after inoculation at different osmotic potentials, disinfested and non-disinfested with sodium hypochlorite solution.

Means followed by the same letter statistically do not differ, according to Tukey's test at a 5\% probability level. 


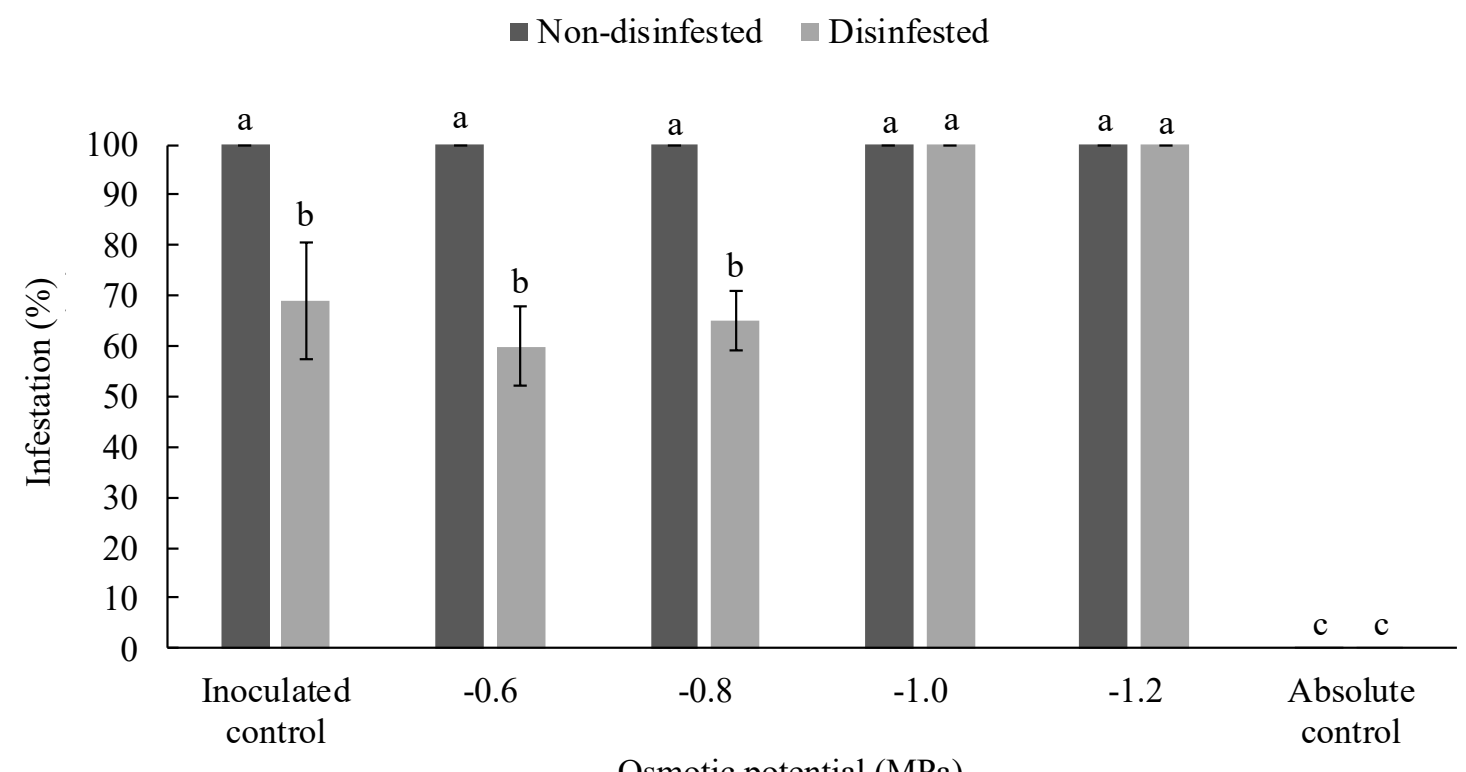

Figure 3. Percentage of normal carrot seedlings seven and 21 days after sowing (DAS). The seeds were inoculated with $A$. radicina at different osmotic potentials.

Means followed by the same letter statistically do not differ, according to Tukey's test at a 5\% probability level.

been inoculated revealed a similar emergence behavior, with values below $6 \%$. By 21 DAS, the non-inoculated seeds scored $64 \%$ of emergence, followed by the seeds tested at $0.6 \mathrm{MPa}$, $0.8 \mathrm{MPa}, 1.0 \mathrm{MPa}$ and the control treatment - these groups did not differ among themselves, with emergence ranging from $12 \%$ to $23 \%$. For the same span, seeds inoculated at $-1.2 \mathrm{MPa}$ had the lowest emergence (3\%).

Non-inoculated seeds showed higher emergence by the $7^{\text {th }}$ DAS, probably because they were maintained in a mannitol-free PDA medium. In turn, seeds tested at the osmotic potential of - $0.6 \mathrm{MPa}$ performed better than the other treatments due to the shorter time they were kept under the testing conditions. In this case, seed imbibition occurred only partly, and the germination proceeded, producing results even better than those of the control treatment.

The high emergence rate observed in the non-inoculated seeds by the $21^{\text {st }}$ DAS was already expected because they, unlike the other treatments, were not impaired by the fungus. On the other hand, a rather expressive reduction was verified in seedling emergence at $1.2 \mathrm{MPa}$, probably due to the longer exposition to the pathogen $(144 \mathrm{~h})$. This fact contributed to intensifying the infective process of the seeds, a conclusion supported by the sanitization testing (Figure 2).

Barrocas et al. (2014) proved that, by adding mannitol at $0,8 \mathrm{MPa}$ in a PDA medium, the number of cotton seedlings tended to drop as the exposure time to that substrate prolonged. Meneses et al. (2011) used the same technique to evaluate cotton seed germination under water stress, but they employed different concentrations of another osmotic agent, PEG 6000. They realized that seed viability and seedling vigor got compromised up from 0.4 MPa.

However, it is worth noticing that the seeds inoculated under no water restriction (control treatment) and at the osmotic potentials of $0.6 \mathrm{MPa}, 0.8 \mathrm{MPa}$ and $1.0 \mathrm{MPa}$ also exhibited high infection indices, as evidenced by the percentage of abnormal seedlings attained in the germination test (Figure 1). By contrasting the results of emergence and germination, it became clear that the higher number of abnormal seedlings was scored by the latter test, probably because of the different conditions provided during the procedures - in this case, the germination settings were more favorable to the fungus growth. In similar studies, Machado et al. (2004) and Araújo et al. (2006) also detected a significant reduction in cotton seedling emergence as the seeds remained longer in contact with the ramulose agent, in substrates with water restriction.

\section{Conclusions}

Employing mannitol as an osmosis-controlling agent at $1.0 \mathrm{MPa}$ and $1.2 \mathrm{MPa}$ does not significantly compromise $A$. radicina growth. Such conditions promote the highest infection rates and, consequently, the reduction of normal seedling emergence and the substantial increase in the number of abnormal ones. Remarkably, the osmotic potential of 
1.2 MPa produces the lowest emergence rates after 21 days of sowing. Therefore, the use of mannitol in a PDA medium at 1.2 $\mathrm{MPa}$ is an efficient method for infecting carrot seeds with the fungus $A$. radicina, for either epidemiological purposes or seed health management.

\section{References}

ARAÚJO, D.V.; POZZA, E.A.; MACHADO, J.C.; ZAMBENEDETTI, E.B.; CELANO, F.; CARVALHO, E.M.; CAMARGOS, V. Influência da temperatura e do tempo de inoculação das sementes de algodão na transmissibilidade de Colletotrichum gossypii var. cephalosporioides. Fitopatologia Brasileira, v.31, n.1, p.35-40, 2006. www.scielo.br/pdf/fb/v31n1/a06v31n1.pdf

ÁVILA, M.R.; BRACCINI, A.L.; SCAPUM, C.R. Influência do estresse hídrico simulado com manitol na germinação de sementes e crescimento de plântulas de canola. Revista Brasileira de Sementes, v.29, n.1, p. 98-106, 2007. www.scielo.br/pdf/\%0D/rbs/v29n1/14.pdf

BARROCAS, E.N.; MACHADO, J.C.; ALVES, M.C.; CORRÊA, C.L. Desempenho de sementes de algodão submetidas à deficiência hídrica e presença de Colletotrichum gossypii var. cephalosporioides. Bioscience Journal, v.30, n.2, p.421-428, 2014. http://www.seer.ufu. br/index.php/biosciencejournal/article/view/17993

BRASIL. Ministério da Agricultura, Pecuária e Abastecimento. Regras para análise de sementes. Ministério da Agricultura, Pecuária e Abastecimento. Secretaria de Defesa Agropecuária. Brasília: MAPA/ACS, 2009. 395p. http://www.agricultura.gov.br/arq_editor/ file/2946_regras_analise_sementes.pdf

CARVALHO, M.C.; MACHADO, J.C.; VON PINHO, E.V.R.; POZZA, E.A.; PRADO, P.E.R. Relação do tamanho das sementes de milho e doses de fungicida no controle de Stenocarpella maydis. Fitopatologia Brasileira, v.29, n.4, p.389-393, 2004. http://www. scielo.br/pdf/fb/v29n4/a05v29n4.pdf

CARVALHO, E.M.; SILVA, U.A.; RODRIGUES, D.C.G.A. Uso da restrição hídrica na detecção de Alternaria dauci e Alternaria radicina em sementes de cenoura (Daucus carota). Tropical Plant Pathology, v.34, n.4, p.216-222, 2009. www.scielo.br/pdf/tpp/ v34n $4 / v 34 n 4 a 03$

COSTA, M.L.N.; MACHADO, J.C.; GUIMARÃES, R.M.; POZZA, E.A.; ORIDE, D. Inoculação de Fusarium oxysporum f. sp. phaseoli em sementes de feijoeiro através de restrição hídrica. Ciência e Agrotecnologia, v.27, n.5, p.1023-1030, 2003. http://www. scielo.br/scielo.php?pid=S1413-70542003000500008\&script $=$ sci abstract\&tlng $=\mathrm{pt}$

GALLI, J.A.; FESSEL, S.A.; PANIZZI, R.C. Effect of Fusarium graminearum and infection index on germination and vigor of maize seeds. Fitopatologia Brasileira, v.30, p.470-474, 2005. http://www. scielo.br/scielo.php?pid=S0100-41582005000500002\&script $=$ sci_ abstract\&tlng $=\mathrm{pt}$
MACHADO, J.C.; OLIVEIRA, J.A.; VIEIRA, M.G.G.C. Uso da restrição hídrica na inoculação de fungos em sementes de milho. Revista Brasileira de Sementes, v.26, n.1, p.88-94, 2001. www.scielo.br/pdf/rbs/v26n1/a10v26n1

MACHADO, J.C.; OLIVEIRA, J.A.; VIEIRA, M.G.G.C.; ALVES, M.C. Uso da restrição hídrica na inoculação de fungos em sementes de algodoeiro. Revista Brasileira de Sementes, v.26, n.1, p.62-67, 2004. http://www.scielo.br/pdf/rbs/v26n1/a10v26n1

MAGUIRE, J.D. Spead of germination-aid in selection and evaluation for seedling emergence and vigour. Crop Science, v.2, p.176177, 1962. https://www.scirp.org/(S(i43dyn45teexjx455qlt3d2q))/ reference/ReferencesPapers.aspx?ReferenceID $=1017323$

MENESES, C.H.S.G.; BRUNO, R.L.A.; FERNANDES, P.D.; PEREIRA, W.E.; LIMA, L.H.G.M; LIMA, M.M.A.; VIDAL, M.S. Germination of cotton cultivar seeds under water stress induced by polyethyleneglycol-6000. Scientia Agricola, v.68, n.2, p.131-138, 2011. http://dx.doi.org/10.1590/S0103-90162011000200001

MENEZES, V.O.; PEDROSO, D.C.; PIVETA, G.; MUNIZ, M.F.B.; MENEZESI, N.L.; GARCIA, D.C.; ETHUR, L.Z.; SANTOS, R.F.; TUNES, L.M. Detecção e influência de Fusarium spp. na qualidade fisiológica de sementes de pepino. Ciência Rural, v.41, n.2, p.193199, 2011. http://www.scielo.br/pdf/cr/v41n2/a855cr3557.pdf

PEDROSO, D.C.; MENEZES, V.O.; MUNIZ, M.F.B.; PIVETA, G.; TUNES, L.M.; MULLER, J.; MENEZES, N.L. Métodos de inoculação de Alternaria alternata e $A$. dauci em sementes de salsa e sua influência na qualidade fisiológica. Revista Brasileira de Sementes v.32, n.3, p.79-85, 2010. http://www.scielo.br/scielo. php?script=sci_arttext\&pid=S0101-31222010000300009

REIS, G.F.; BACCHI, L.M.A.; GAVASSONI, W.L.; HIRATA, L.M.; PONTIM, B.C.A. Viabilidade de armazenamento de sementes de soja inoculadas com Sclerotinia sclerotiorum em meio com restrição hídrica. Summa Phytopathologica, v.40, n.2, p.168-173, 2014. http:// www.scielo.br/pdf/sp/v40n2/v40n2a10.pdf

SOUZA, G.M.; CARDOSO, V.J.M. Effects of different environmental stress on seeds germination. Seed Science Technology, v.28, n.3, p.621-630, 2000. https://repositorio.unesp.br/handle/11449/20224

TEIXEIRA, H.; MACHADO, J.C.; ORIDE, D.; ALVES, M.C.; NODA, A. Técnica de restrição hídrica: efeito sobre Acremonium strictum, protrusão de sementes e obtenção de sementes de milho infetadas. Fitopatologia Brasileira, v.30, p.109-114, 2005. https:// www.researchgate.net/publication/242311943 Tecnica de restricao_hidrica_efeito_sobre_Acremonium_strictum_protrusao_ de_sementes_e_obtencao_de_sementes_de_milho_infetadas 